\title{
Serial Powerpoint Presentasi: Nilai Ekonomi Air di Daerah Karst
}

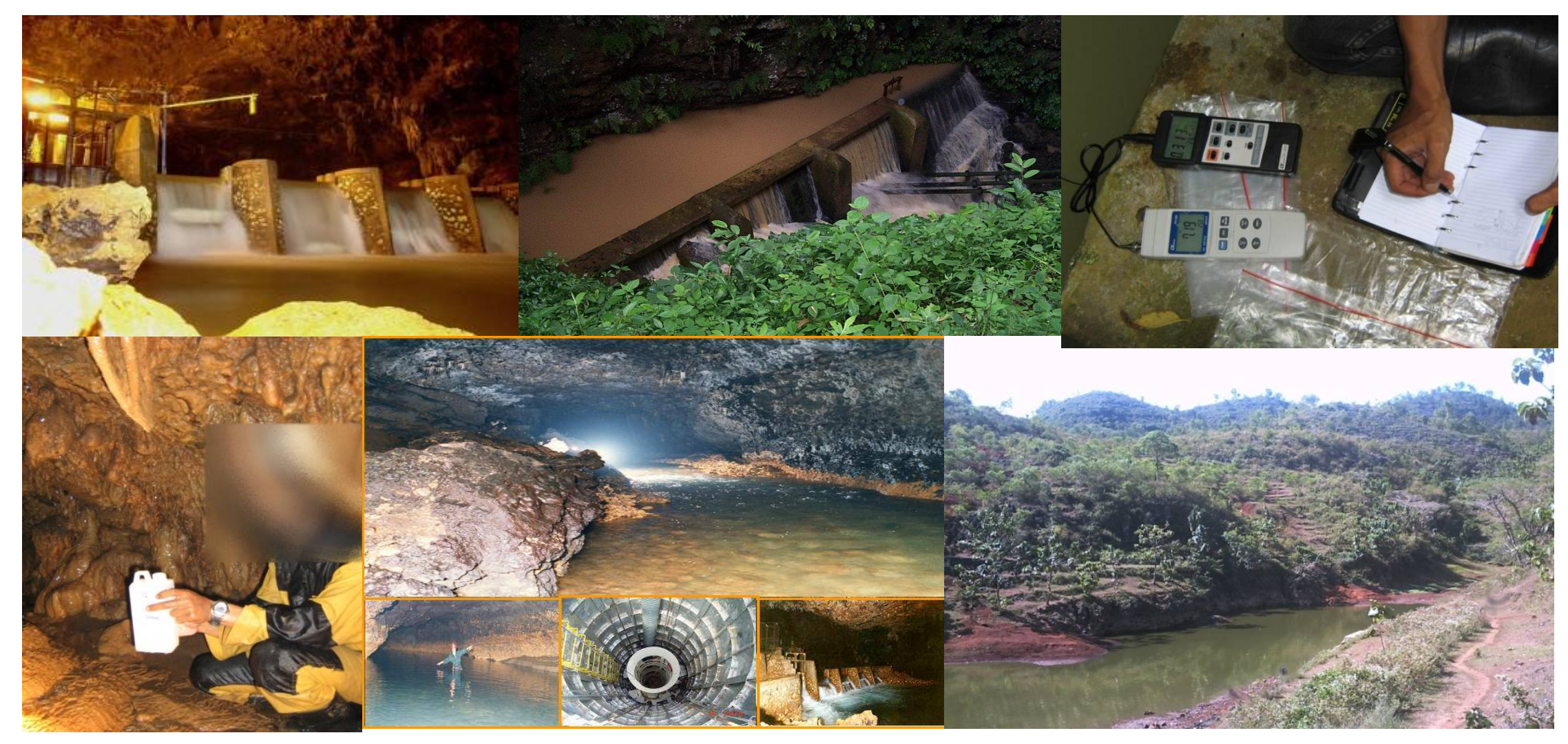

Tjahyo Nugroho Adji Karst Research Group Fak. Geografi UGM 


\section{Air di karst bagian dari siklus air di bumi}

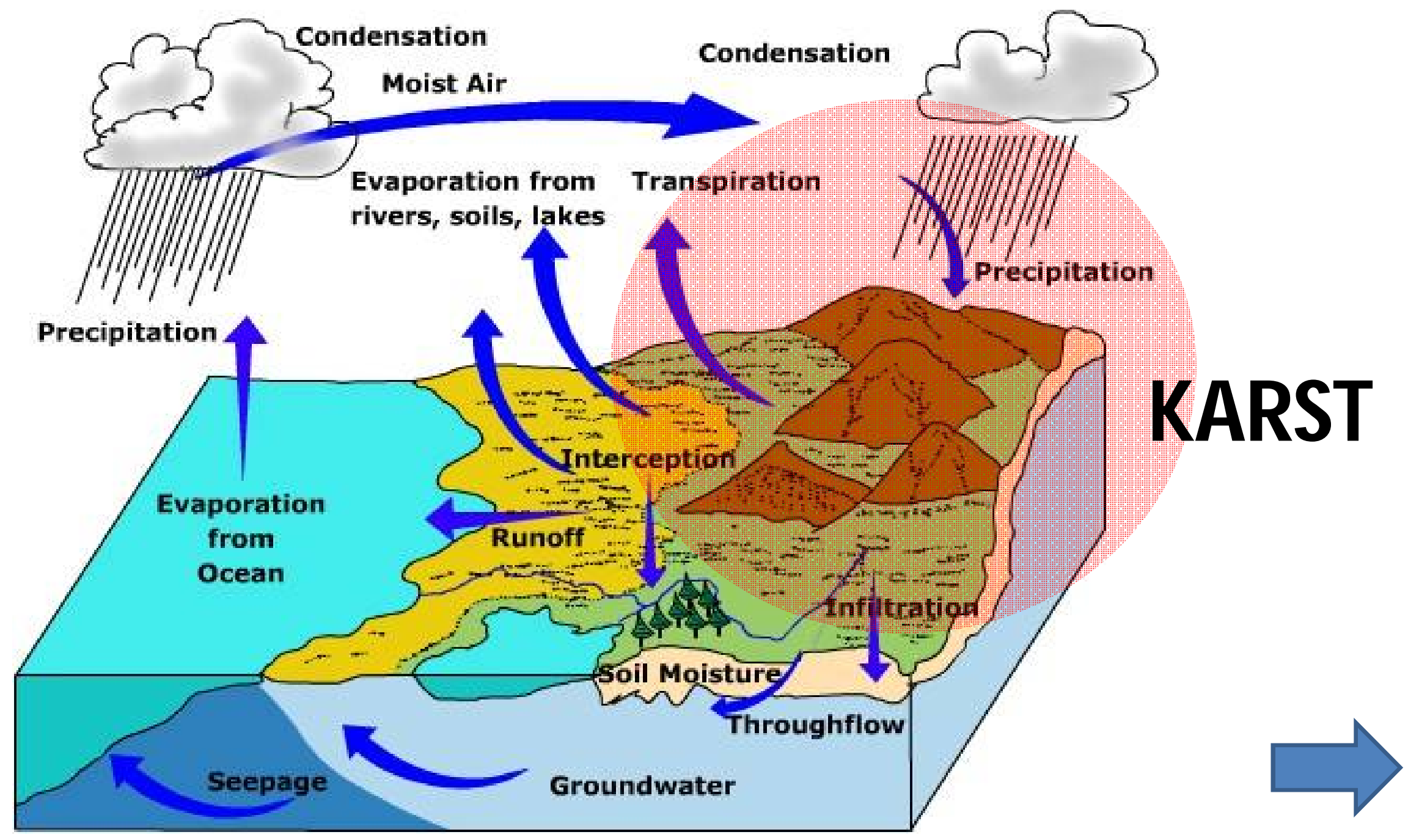




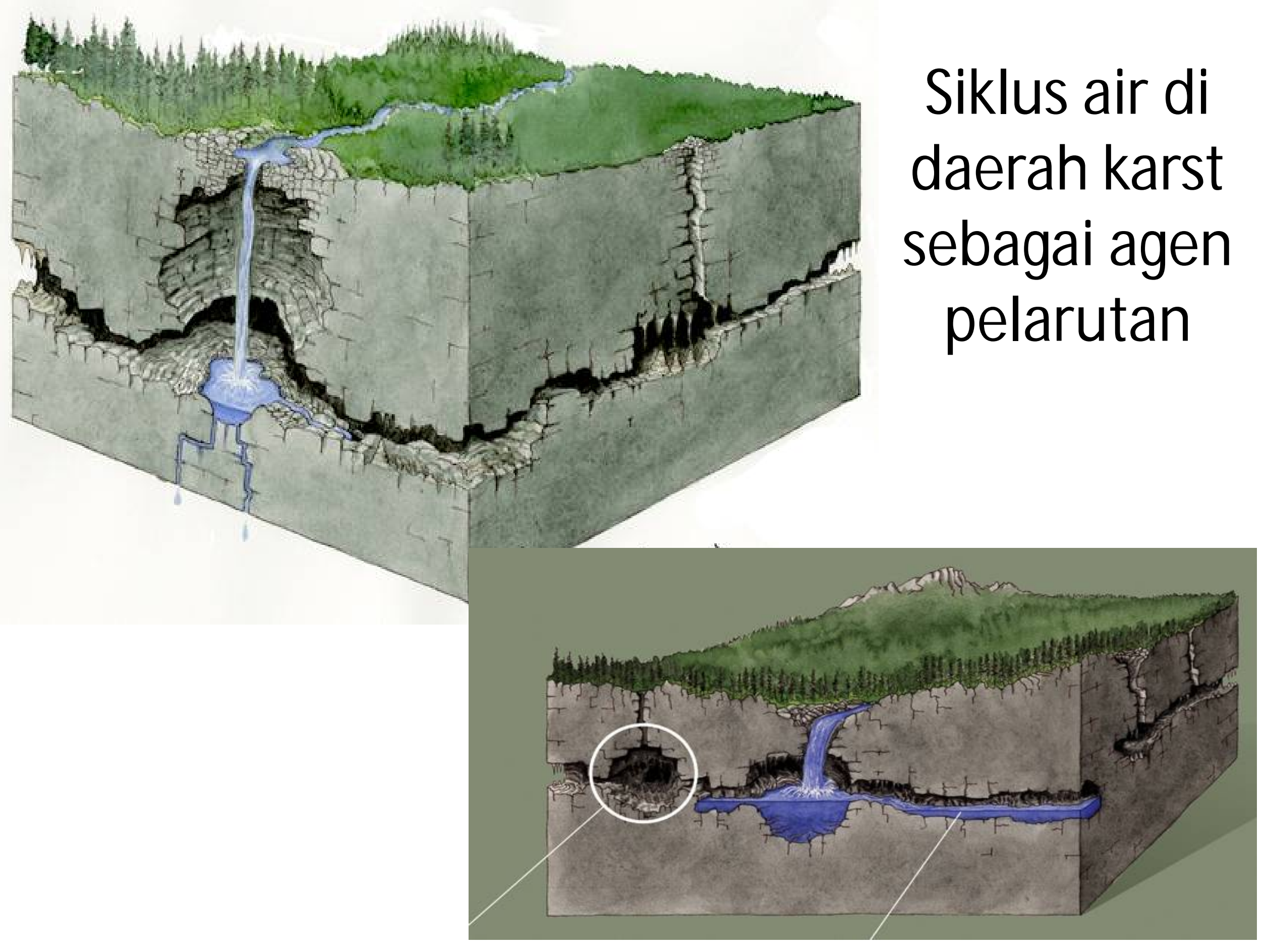




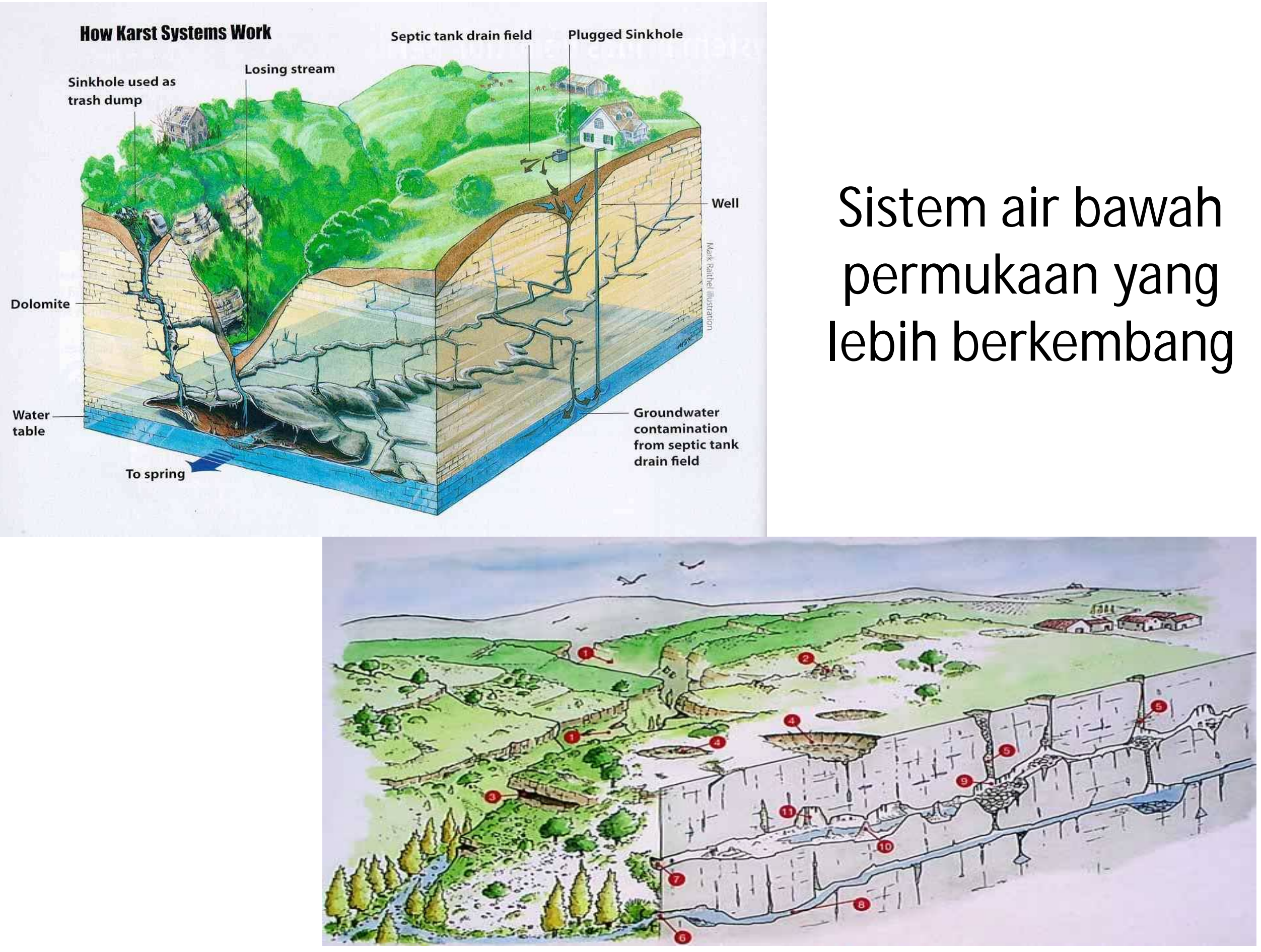




\section{Potensi air di karst (kasus: Gunungsewu)}

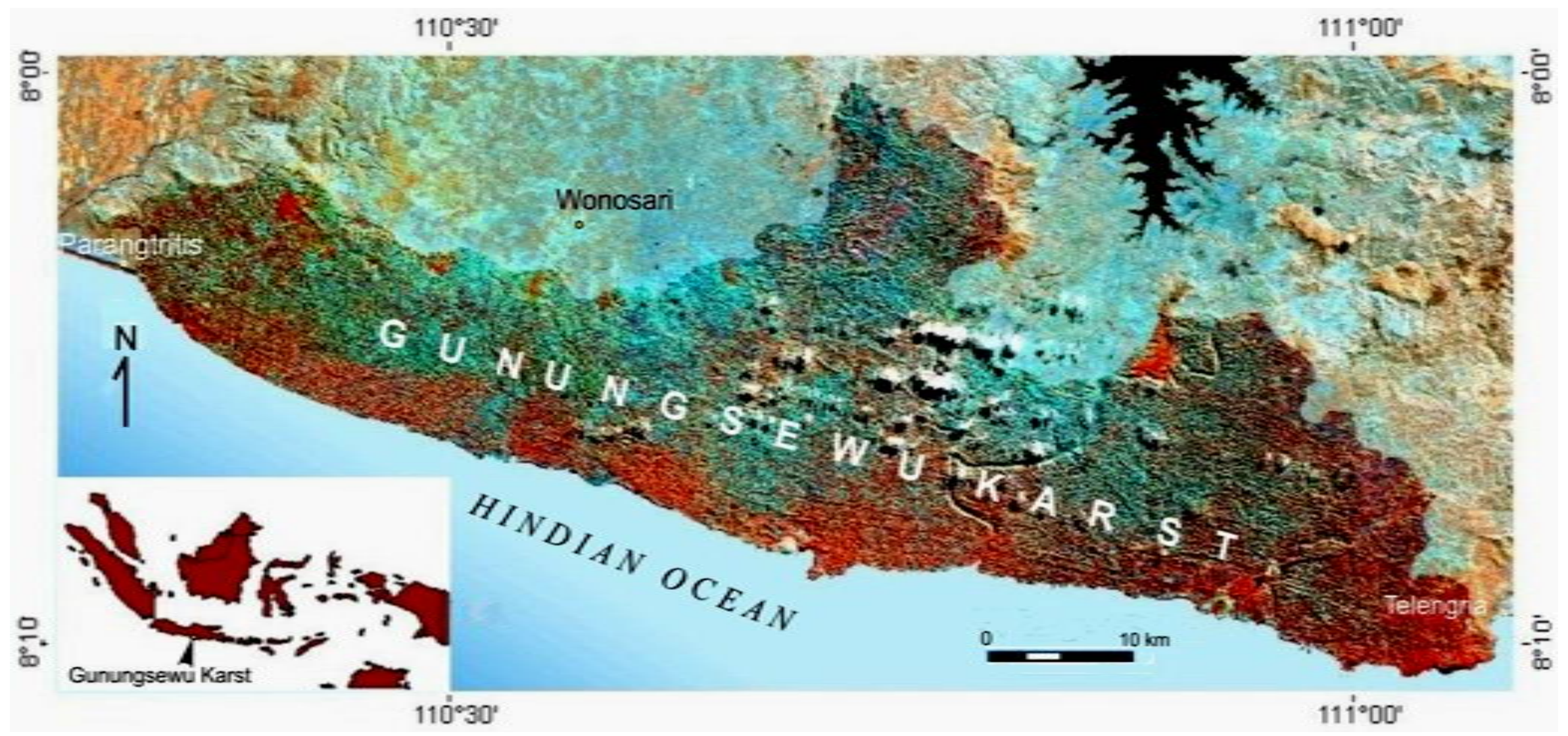

1. Air hujan yang jatuh di karst;

2. Airtanah karst (sungai bawah tanah dan mataair);

3. Telaga karst (doline)

4. Siklus air di karst yang 'memakan' karbon 


\section{Karst Gunung Sewu hanya satu bagian dari banyaknya kawasan karst yang tersebar di Indonesia}

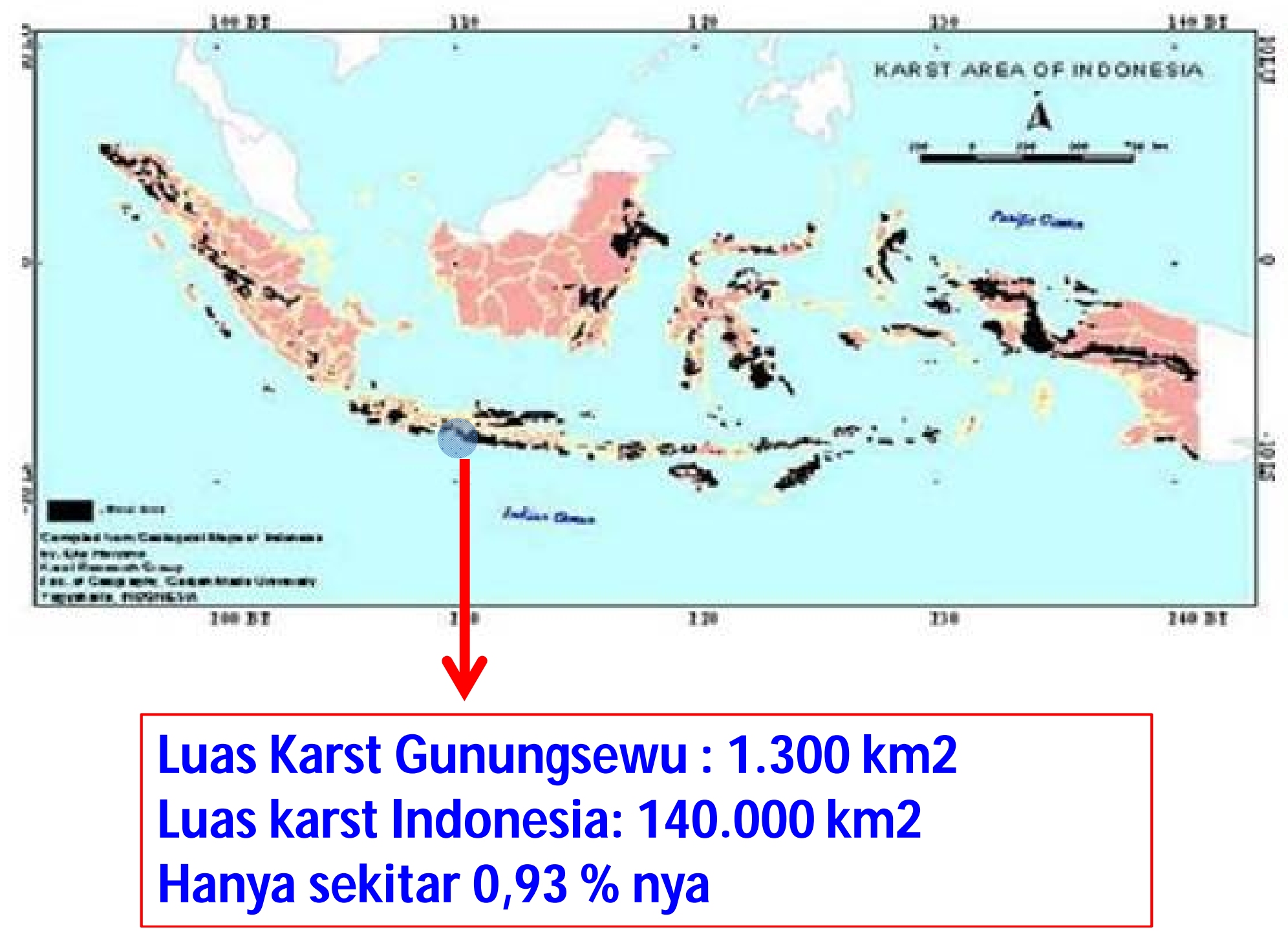




\section{Potensi air hujan karst Gunungsewu}

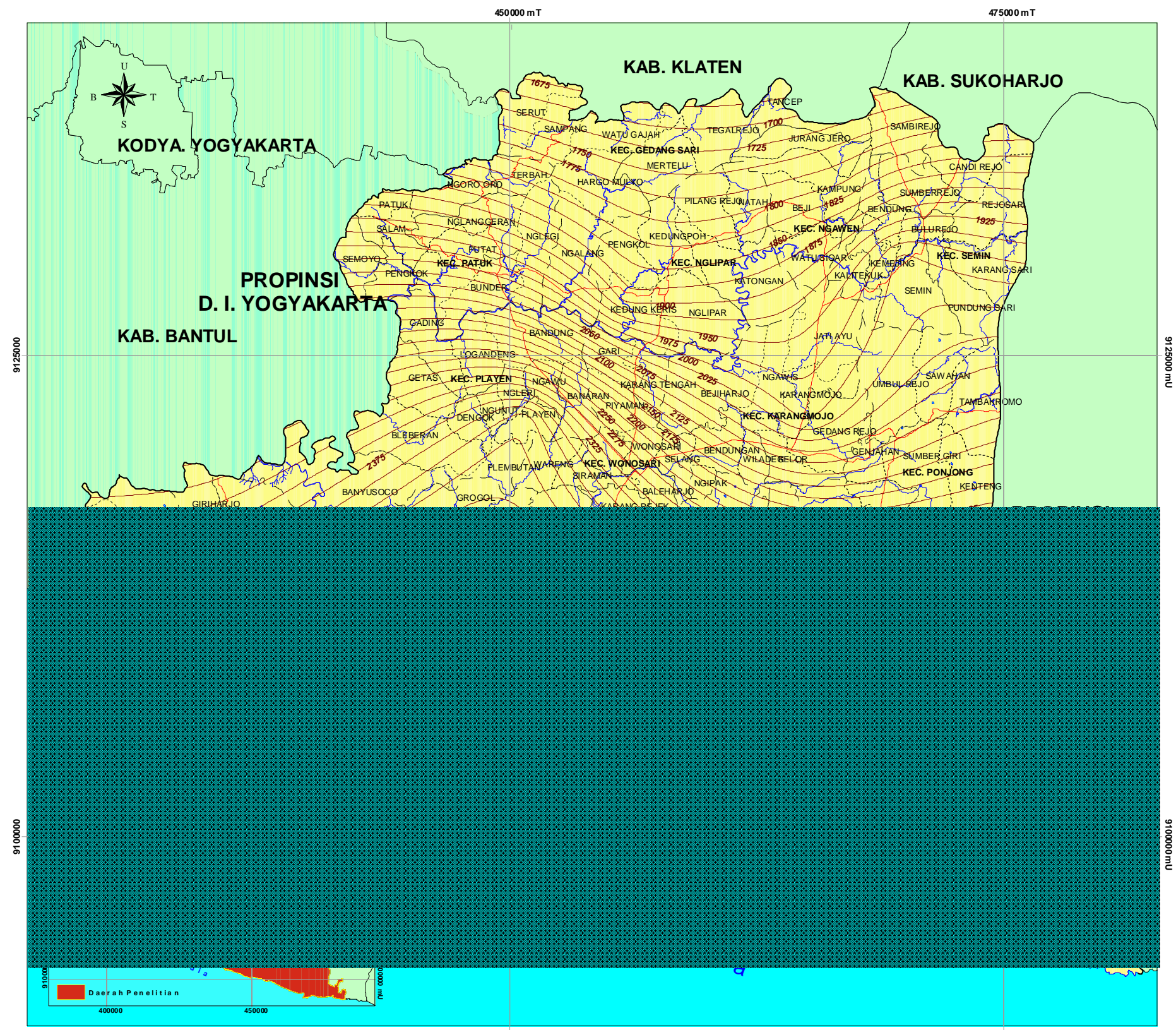

PETA ISOHYET DAERAH PENELITIAN KABUPATEN GUNUNGKIDUL D.I. YOGYAKARTA

$\begin{array}{ll}\text { Proyeksi } & \text { : Transverse Mercator } \\ \text { Sistem Gridi } \\ \text { Datum Horizontal : }\end{array}$ \begin{tabular}{ll} 
Datum Horizontal : $:$ WGS 84 \\
Zone & $50 \mathrm{M}$ \\
\hline
\end{tabular}

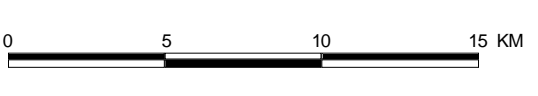

LEGENDA

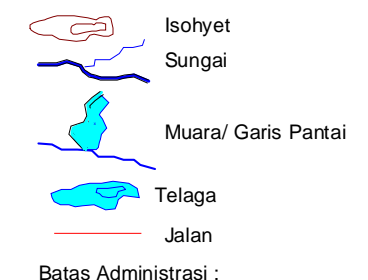

Kabupaten

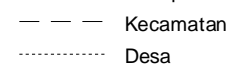




\section{Hujan tertangkap}

Atap Pemanen Air Hujan

Luas Proyeksi Datar Minimal $5 \times 6 \mathrm{~m}^{2}$

Volume hujan tahunan

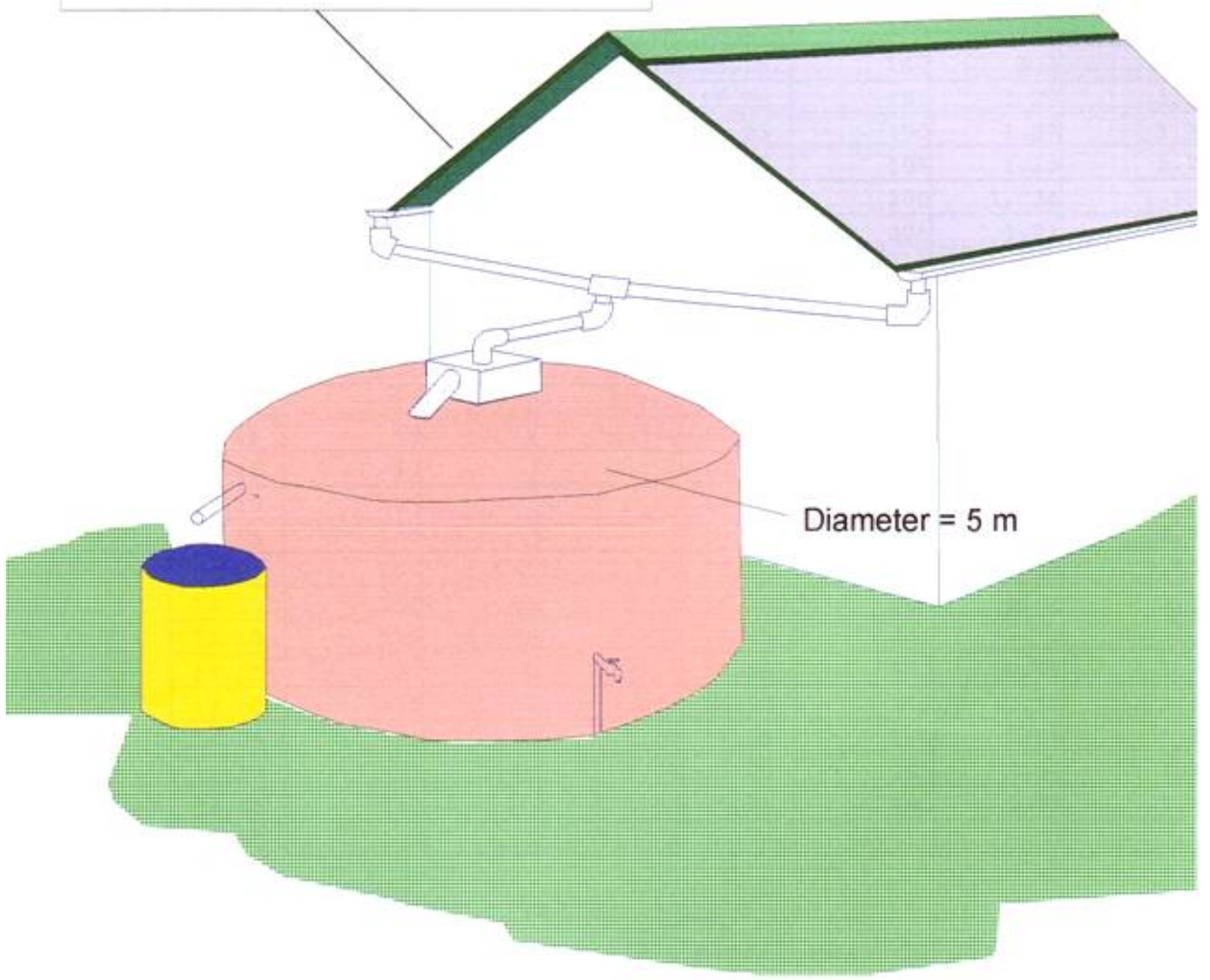
yang bisa ditangkap = hasil perkalian antara luas atap yang mungkin untuk menangkap hujan $\left(\mathrm{m}^{2}\right)$, jumlah Kepala Keluarga (KK) tiap desa, serta tebal hujan yang jatuh di suatu desa ( $\mathrm{m}^{3} /$ tahun). 


\begin{tabular}{|c|c|c|c|c|c|c|c|c|c|c|c|}
\hline No & Kecamatan & Desa & $\begin{array}{c}\text { Hujan } \\
\text { tertangkap (m3/th) }\end{array}$ & No & Kecamatan & Desa & $\begin{array}{c}\text { Hujan } \\
\text { tertangkap (m3/th }\end{array}$ & & & & \\
\hline 18 & \multirow{8}{*}{ Ponjong } & Banyusoco & 157612.1 & 39 & \multirow{7}{*}{ Sapto Sari } & Jetis & 165731.4 & & & & \\
\hline 19 & & Gading & 158450.8 & 40 & & Kanigoro & 260041.1 & & & & \\
\hline 20 & & Bedoyo & 98580.0 & 41 & & Kepek & 212992.4 & & & & \\
\hline 21 & & Gombang & 84862.5 & 42 & & Krambil Sawit & 213173.2 & & & & \\
\hline 22 & & Karang Asem & 64979.2 & 43 & & Monggol & 211922.5 & & & & \\
\hline 23 & & Kenteng & 83034.6 & 44 & & Nglora & 122330.0 & & & & \\
\hline 24 & & Ponjong & 134530.0 & 45 & & Planjan & 216787.2 & & & & \\
\hline 25 & & Sumber Giri & 126427.4 & 46 & \multirow{3}{*}{ Semanu } & Candirejo & 219690.4 & & & & \\
\hline 26 & \multirow{5}{*}{ Purwosari } & Giriasih & 39480.0 & 47 & & Dadapayu & 221512.5 & & & & \\
\hline 27 & & Giricahyo & 105105.0 & 48 & & Ngeposari & 237723.2 & & & & \\
\hline 28 & & Girijati & 64718.8 & 49 & \multirow{5}{*}{ Tanjungsari } & Banjarejo & 214238.4 & & & & \\
\hline 29 & & Giripurwo & 219285.0 & 50 & & Hargosari & 208076.4 & & & & \\
\hline 30 & & Giritirto & 88931.3 & 51 & & Kemadang & 249867.3 & & & & \\
\hline 31 & \multirow{8}{*}{ Rongkop } & Bohol & 47115.0 & 52 & & Kemiri & 188760.0 & & & & \\
\hline 32 & & Botodayakan & 143762.5 & 53 & & Ngestiharjo & 235009.8 & & & & \\
\hline 33 & & Karangwuni & 113680.0 & 54 & \multirow{5}{*}{ Tepus } & Giripanggung & 214068.8 & \multirow{2}{*}{ No } & \multirow{2}{*}{ Kecamatan } & \multirow{2}{*}{ Desa } & \multirow{2}{*}{$\begin{array}{c}\text { Hujan } \\
\text { tertangkap (m3/th) }\end{array}$} \\
\hline 34 & & Melikan & 107231.3 & 55 & & Purwodadi & 253643.4 & & & & \\
\hline 35 & & Petir & 132345.0 & 56 & & Sidoharjo & 220684.8 & 1 & \multirow{8}{*}{ Girisubo } & Balong & 160811.3 \\
\hline 36 & & Pringombo & 116610.0 & 57 & & sumber Wungu & 207350.0 & 2 & & Jepitu & 196700.0 \\
\hline 37 & & Pucanganom & 115100.1 & 58 & & Tepus & 288850.0 & 3 & & Jeruk wudel & 82550.7 \\
\hline 38 & & Semugih & 127386.3 & 59 & & Wunung & 98132.7 & 4 & & Karangawen & 59542.7 \\
\hline & & & & & & & & 5 & & Nglindur & 111915.0 \\
\hline & & & & & & & & 6 & & Pucung & 145812.4 \\
\hline & & & & & & & & 7 & & Songbanyu & 164279.2 \\
\hline & & & & & & & & 8 & & Tileng & 190299.5 \\
\hline & & & & & & & & 9 & & Giring & 97592.5 \\
\hline & & & & & & & & 10 & Paliyan & Karang Asem & 239117.5 \\
\hline & & & & & & & & 11 & & Karang Duwet & 193792.5 \\
\hline & & & & & & & & 12 & & Giriharjo & 134902.6 \\
\hline & & & & & & & & 13 & & Girikarto & 158943.8 \\
\hline & & & & & & & & 14 & Pangqang & Girimulyo & 207750.0 \\
\hline & & & & & & & & 15 & & Girisekar & 272911.8 \\
\hline & & & & & & & & 16 & & Girisuko & 200114.4 \\
\hline & & & & & & & & 17 & & Giriwungu & 94813.8 \\
\hline
\end{tabular}




\section{Airtanah karst}

Disimpan pada 3 jenis komponen aliran karst

a) aliran diffuse

b) _aliran fissure

c) aliran conduit
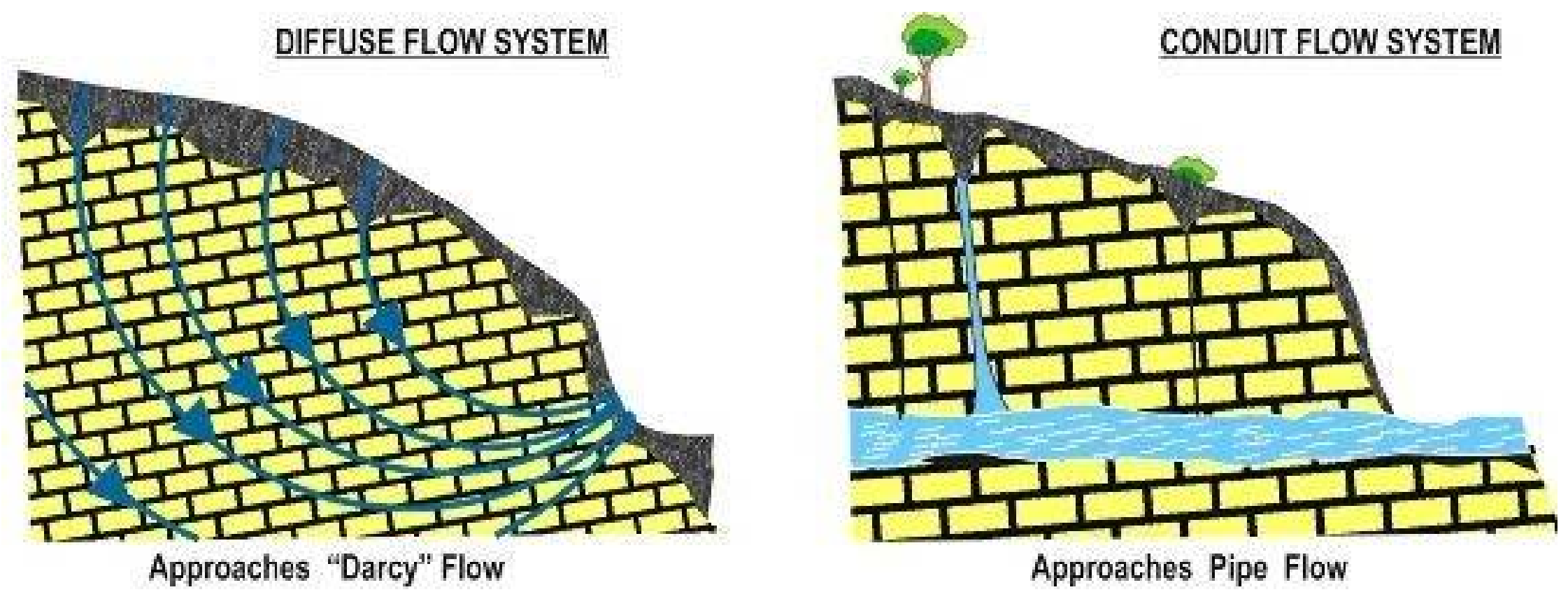


\section{a. Aliran Diffuse}

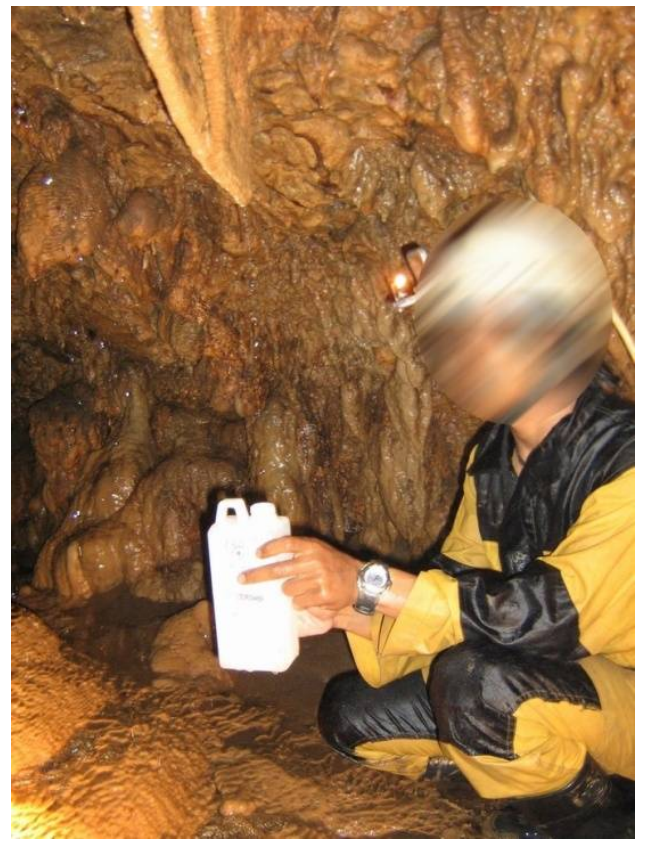

$\square$ mengisi SBT secara seragam dan perlahan-lahan

$\square$ melalui retakan berukuran $\mathbf{1 0}^{-\mathbf{3}}$ - $\mathbf{1 0} \mathrm{mm}$

$\square$ sebagai aliran infiltrasi dari zone simpanannya di permukaan bukit karst

$\square$ air tetesan atau rembesan pada ornamen gua

$\square$ debit andalan saat kemarau (satu-satunya) 

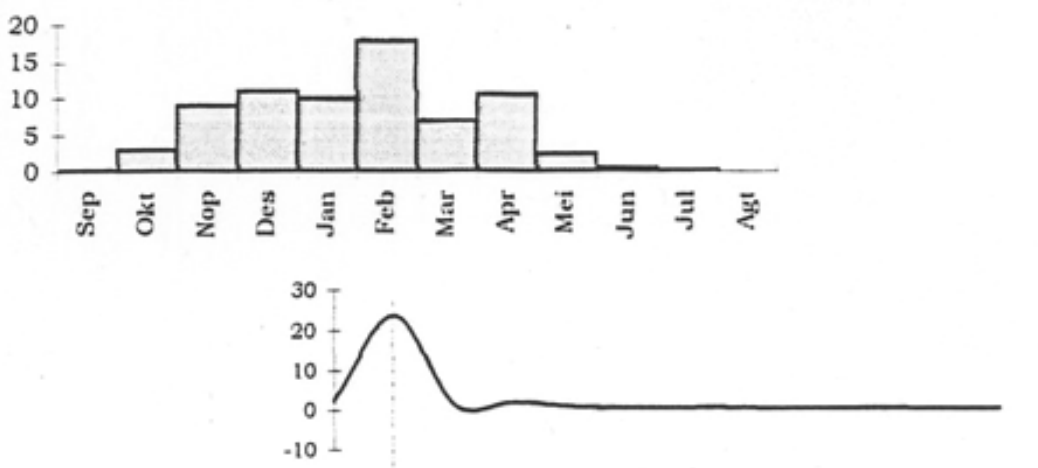

SELONJONO (lt/dt)

Tinggi tempat $475 \mathrm{~m}$ dpal

Tipe terdrainase bebas

Perenial

Jernih di musim penghujan

GREMENG (m3/dt)

Tinggi tempat $250 \mathrm{~m} \mathrm{dpal}$

Tipe resurgence

Perenial

Keruh dimusim penghujan

\section{TELENG (lt/dt)}

Tinggi tempat $250 \mathrm{~m} \mathrm{dpal}$

Tipe terbendung

Perenial

Jernih di musim penghujan

PONJONG (1t/dt)

Tinggi tempat $225 \mathrm{~m} \mathrm{dpal}$

Tipe terbendung

Perenial

Jernih di musim penghujan

BENDUNGAN (m3/dt)

Tinggi tempat $437,5 \mathrm{~m}$ dpal

Tipe terbendung

Perenial

Jernih di musim penghujan

\section{GEDAREN (lt/dt)}

Tinggi tempat $250 \mathrm{~m}$ dpa

Tipe terbendung

Perenial

Jernih di musim penghujan

\section{Dengan aliran} diffuse ini, maka mataair karst dan SBT akan selalu mengalir sepanjang tahun (perenial) 

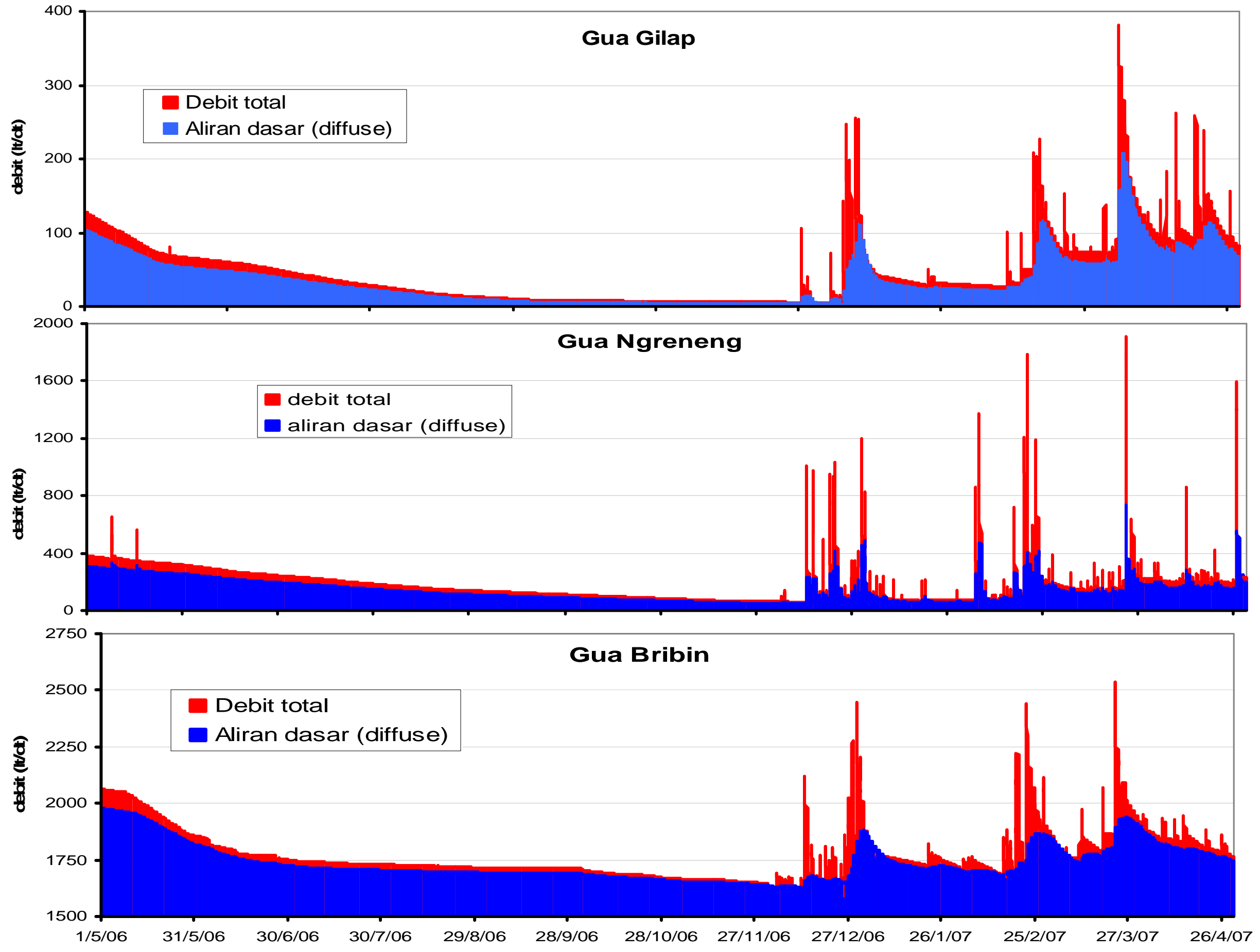


\section{b. Aliran Conduit}

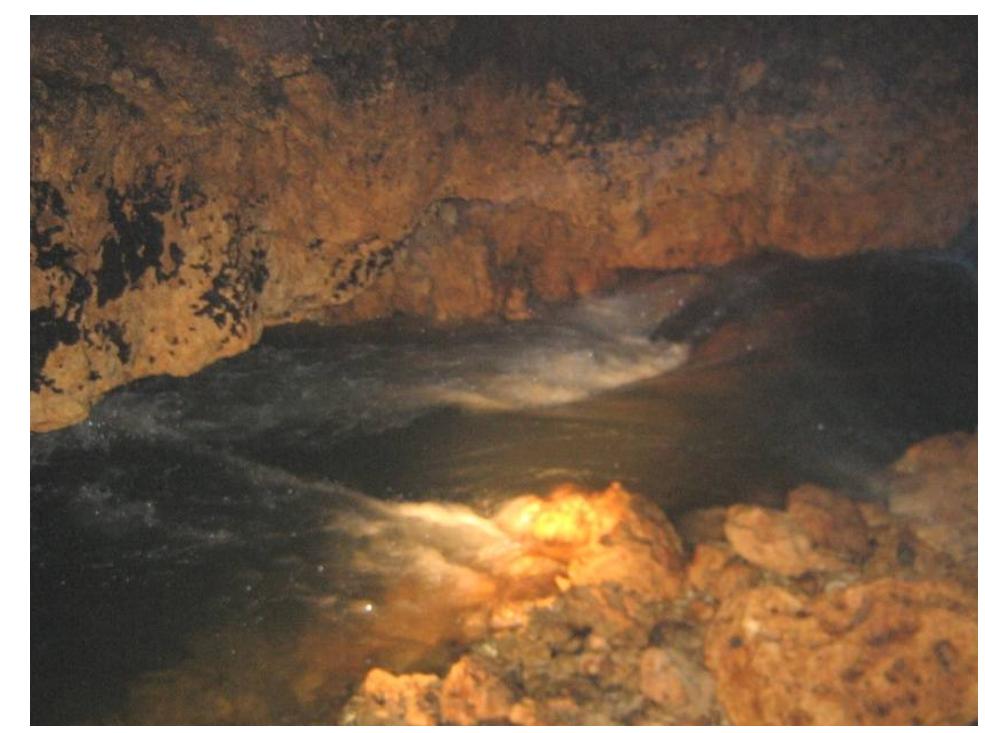

$\square$ mengisi SBT dengan cepat

$\square$ berhubungan langsung dengan air permukaan

$\square$ melalui retakan berukuran $10^{2}-10^{4} \mathrm{~mm}$ atau lebih

$\square$ dipasok ketika hujan dan mengakibatkan banjir pada SBT

$\square$ keruh dan bahan pencemar ikut masuk bersama aliran ini

$\square$ tidak ada saat kemarau 


\section{c. Aliran fissure (pertengahan antara diffuse $\&$ conduit)}

- fissure flow, komponen aliran pengisi sungai bawah tanah dari akuifer yang mengalir melalui retakan-retakan pada batuan gamping yang berukuran (Bonacci, 1990) 10-10² $\mathrm{mm}$ 
Akibat dari kombinasi 3 tipe aliran ini, maka airtanah karst akan dapat dijumpai pada:

1. M ataair karst

2. Sungai bawah tanah

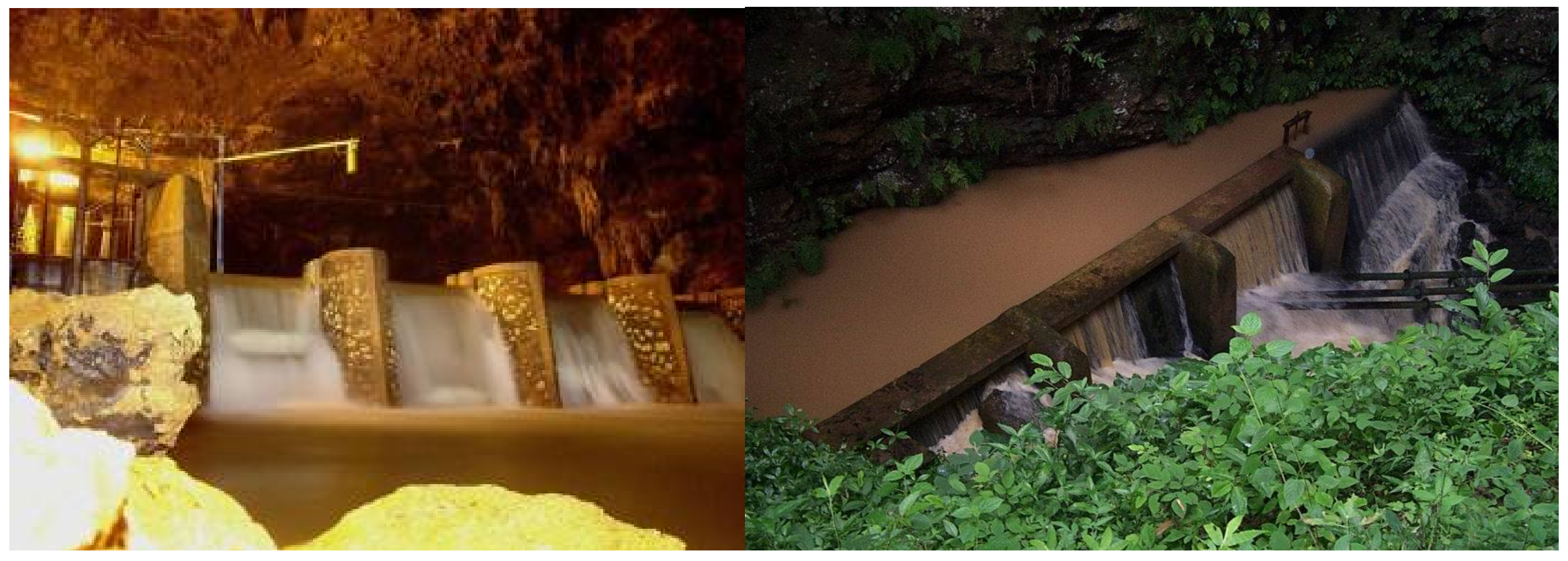




\begin{tabular}{|c|c|c|c|c|c|c|c|c|c|c|c|c|c|c|}
\hline No & Kecamatan & Desa & $\begin{array}{l}\text { mataair } \\
\text { (m3/th) }\end{array}$ & $\begin{array}{c}\text { Debit SBT } \\
(\mathrm{m} 3 / \mathrm{th})\end{array}$ & No & Kecamatan & Desa & $\begin{array}{l}\text { mataair } \\
\text { (m3/th) }\end{array}$ & $\begin{array}{c}\text { Debit SBT } \\
(\mathrm{m} 3 / \mathrm{th})\end{array}$ & No & Kecamatan & Desa & $\begin{array}{l}\text { mataair } \\
(\mathrm{m} 3 / \mathrm{th})\end{array}$ & $\begin{array}{c}\text { Debit SBT } \\
\text { (m3/th) }\end{array}$ \\
\hline 1 & \multirow[b]{7}{*}{ Girisubo } & Balong & 1576800 & & 18 & & Banyusoco & 11352960 & & 39 & \multirow[b]{6}{*}{ Sapto Sari } & Jetis & 0 & \\
\hline 3 & & Jeruk wudel & 0 & 788400 & 20 & \multirow[b]{6}{*}{ Ponjong } & Bedoyo & 0 & & 41 & & Kepek & 0 & \\
\hline 4 & & Karangawen & 0 & & 21 & & Gombang & 0 & & 42 & & Krambil Saw & 0 & 315.4 \\
\hline 5 & & Nglindur & 0 & & 22 & & Karang Asem & 0 & & 43 & & Monggol & 0 & 22075.2 \\
\hline 6 & & Pucung & 315360 & & 23 & & Kenteng & 315360 & 630720 & 44 & & Nglora & 0 & \\
\hline 7 & & Songbanyu & 0 & & 24 & & Ponjong & 12614400 & & 45 & & Planjan & 0 & 31536 \\
\hline 8 & & Tileng & 315360 & & 25 & & Sumber Giri & 42258240 & & 46 & \multirow[b]{3}{*}{ Semanu } & Candirejo & 0 & 883008 \\
\hline 9 & \multirow[b]{3}{*}{ Paliyan } & Giring & 0 & 252288 & 26 & \multirow[b]{4}{*}{ Purwosari } & Giriasih & 315360 & & 47 & & Dadapayu & 0 & 26490240 \\
\hline 10 & & Karang Asem & 0 & & 27 & & Giricahyo & 0 & & 48 & & Ngeposari & 23336640 & 23336640 \\
\hline 11 & & Karang Duwet & 630720 & & 28 & & Girijati & 8830080 & & 49 & \multirow[b]{4}{*}{ Tanjungsari } & Banjarejo & 946080 & \\
\hline 13 & \multirow[b]{5}{*}{ Panggang } & Girikarto & 0 & & 30 & & Giritirto & 2522880 & & 51 & & Kemadang & 0 & 258595200 \\
\hline 14 & & Girimulyo & 0 & 220752 & 31 & \multirow[b]{8}{*}{ Rongkop } & Bohol & 0 & & 52 & & Kemiri & 0 & 126144 \\
\hline 15 & & Girisekar & 0 & 47304 & 32 & & Botodayakan & 0 & 15768 & 53 & & Ngestiharjo & 0 & \\
\hline 16 & & Girisuko & 3153600 & 15768 & 33 & & Karangwuni & 0 & 31536 & 54 & \multirow{6}{*}{ Tepus } & Siripanggund & 0 & 63072 \\
\hline \multirow[t]{5}{*}{17} & & Giriwungu & 0 & & 34 & & Melikan & 0 & & 55 & & Purwodadi & 2207520 & \\
\hline & & & & & 35 & & Petir & 0 & & 56 & & Sidoharjo & 15768000 & 157680 \\
\hline & & & & & 36 & & Pringombo & 0 & & 57 & & umber Wung & 0 & 126144 \\
\hline & & & & & 37 & & \begin{tabular}{|l|} 
Pucanganom \\
\end{tabular} & 0 & 81993.6 & 58 & & Tepus & 64648800 & 6307200 \\
\hline & & & & & 38 & & Semugih & 0 & & 59 & & Wunung & 1135296 & 47304 \\
\hline
\end{tabular}

\section{TOTAL POTENSI \\ MATAAIR \& SBT \\ $521.337 .699,4 \mathrm{~m}^{3} /$ th}




\section{Telaga karst (dolin)}

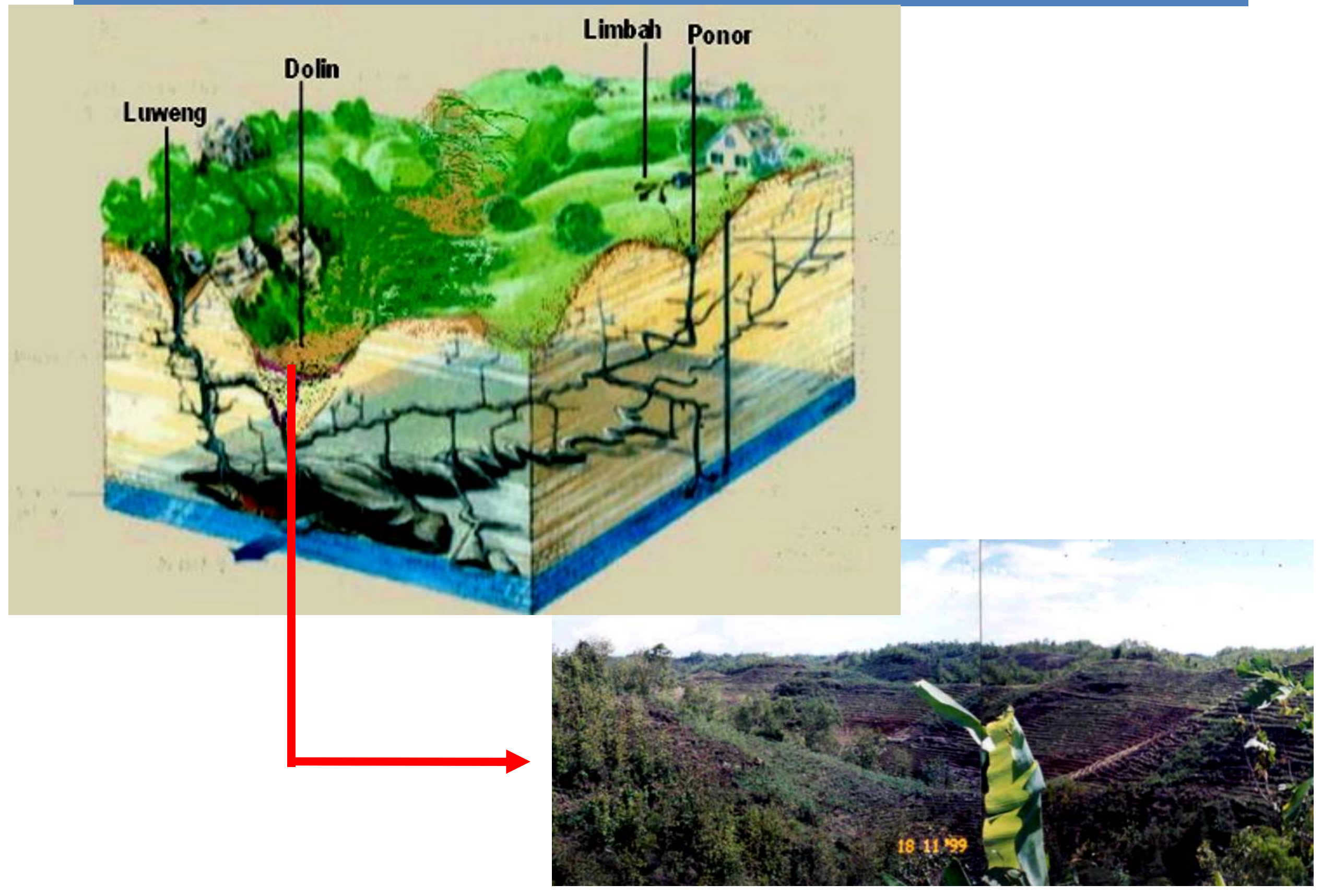




\begin{tabular}{|l|c|c|c|}
\hline \multicolumn{1}{|c|}{ Kecamatan } & $\begin{array}{c}\text { Jumlah } \\
\text { Telaga }\end{array}$ & $\begin{array}{c}\text { Telaga yang } \\
\text { Kering }\end{array}$ & $\begin{array}{c}\text { Telaga } \\
\text { mengalami } \\
\text { Pendangkalan }\end{array}$ \\
\hline Purwosari & 31 & 19 & 17 \\
\hline Panggang & 22 & 12 & 11 \\
\hline Tepus & 32 & 29 & 32 \\
\hline Tanjungsari & 27 & 26 & 27 \\
\hline Semanu & 42 & 37 & 41 \\
\hline Ponjong & 21 & 14 & 4 \\
\hline Rongkop & 49 & 36 & 31 \\
\hline Girisubo & 27 & 22 & 26 \\
\hline Saptosari & 21 & 15 & 12 \\
\hline Paliyan & 10 & 7 & 4 \\
\hline \multicolumn{1}{|c|}{ Jumlah } & 282 & 217 & 205 \\
\hline & & & \\
\hline
\end{tabular}




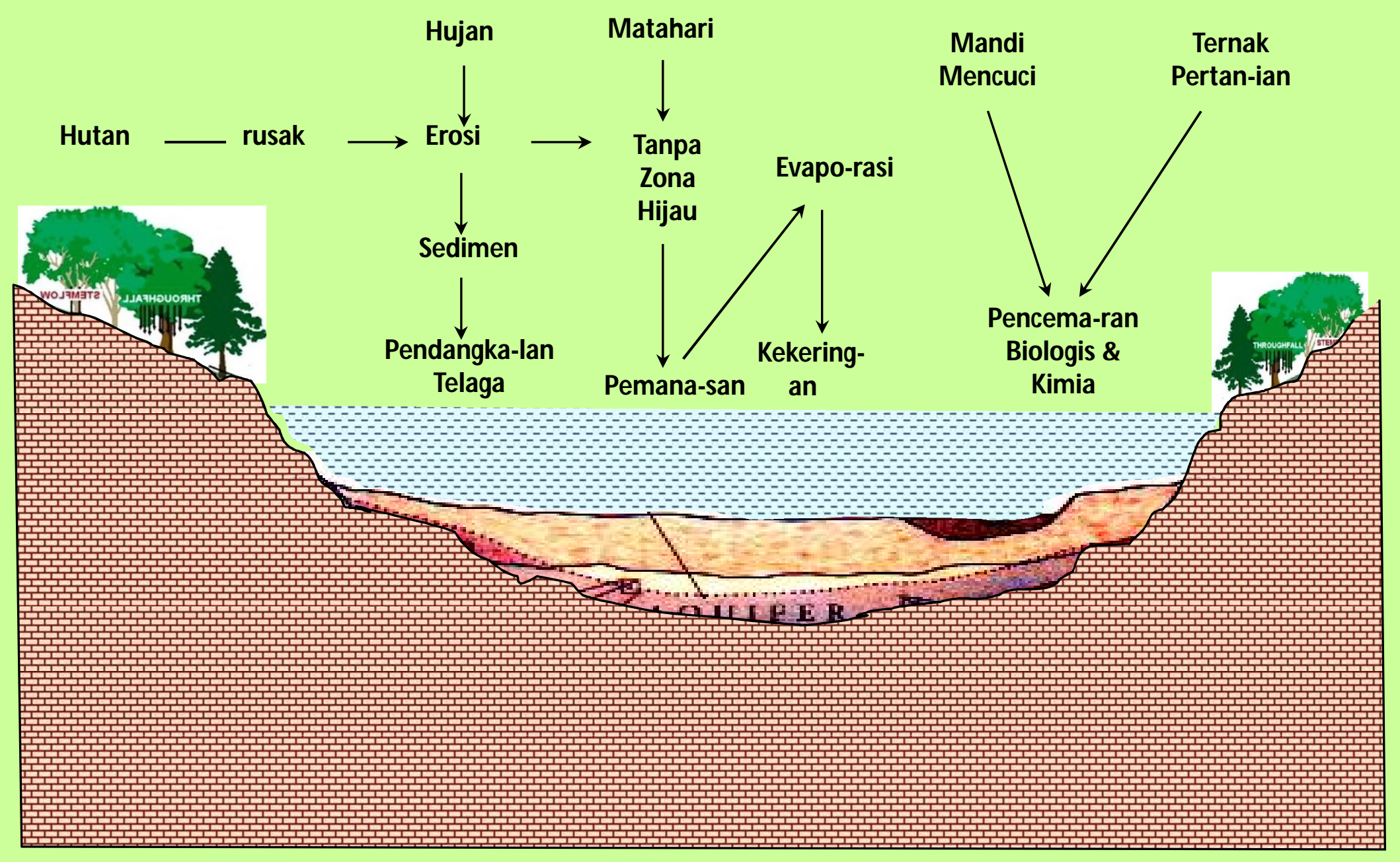



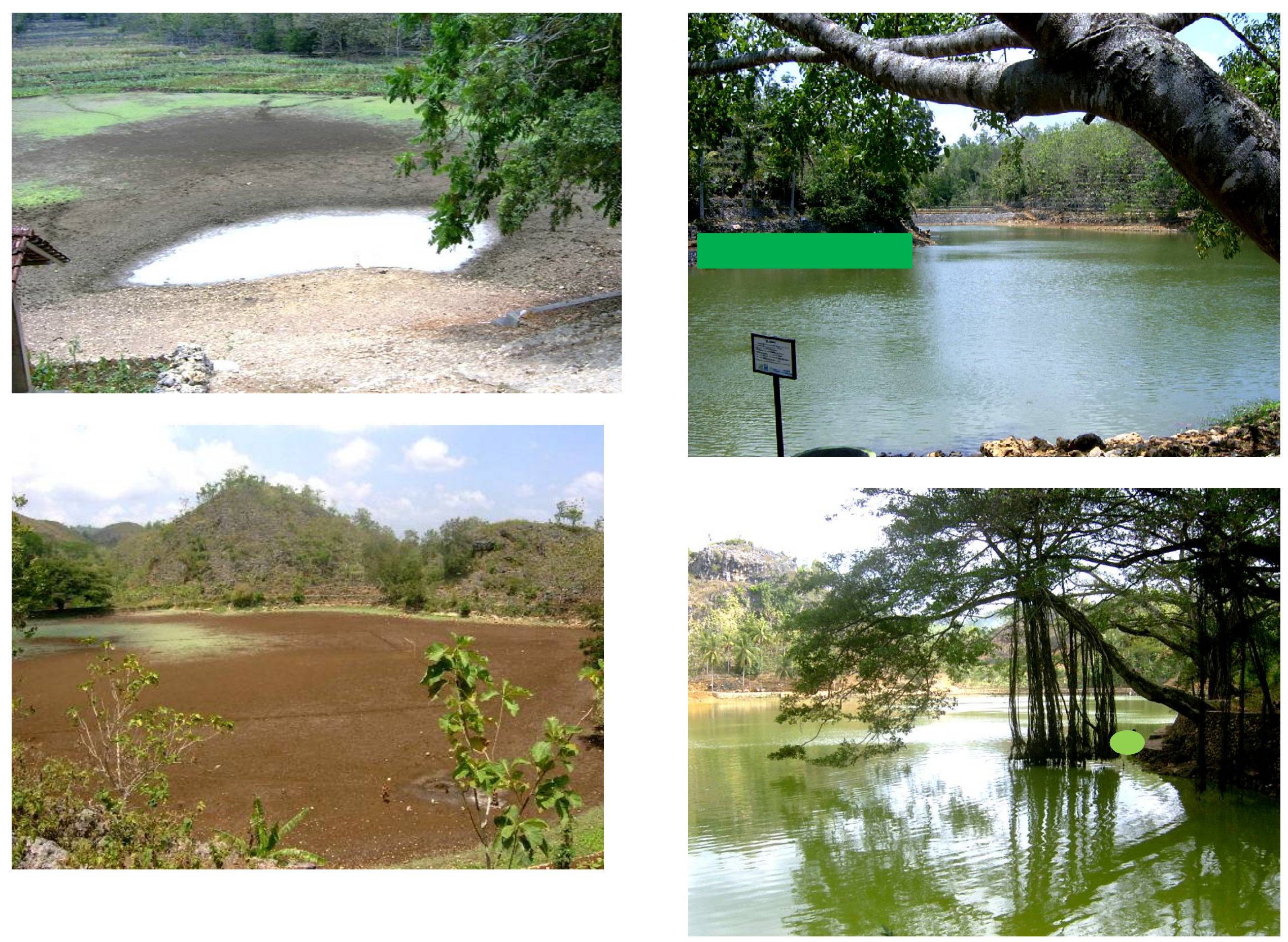


\begin{tabular}{|c|c|c|c|c|c|c|c|c|c|c|c|}
\hline \multirow{2}{*}{ No } & \multirow{2}{*}{ Kecamatan } & \multirow{2}{*}{ Desa } & Vol Air Telaga & \multirow{2}{*}{ No } & \multirow{2}{*}{ Kecamatan } & \multirow{2}{*}{ Desa } & Vol Air Telaga & \multirow{2}{*}{ No } & \multirow{2}{*}{ Kecamatan } & \multirow{2}{*}{ Desa } & \multirow{2}{*}{$\begin{array}{c}\text { Vol Air Telaga } \\
\text { (m3/th) }\end{array}$} \\
\hline & & & (m3/th) & & & & (m3/th) & & & & \\
\hline 1 & \multirow{8}{*}{ Girisubo } & Balong & 0 & 18 & & Banyusoco & 0 & 39 & \multirow{7}{*}{ Sapto Sari } & Jetis & 608000 \\
\hline 2 & & Jepitu & 0 & 19 & & Gading & 0 & 40 & & Kanigoro & 0 \\
\hline 3 & & Jeruk wudel & 0 & 20 & \multirow{6}{*}{ Ponjong } & Bedoyo & 10600 & 41 & & Kepek & 991500 \\
\hline 4 & & Karangawen & 1750 & 21 & & Gombang & 17999 & 42 & & Krambil Sawit & 32500 \\
\hline 5 & & Nglindur & 17250 & 22 & & Karang Asem & 0 & 43 & & Monggol & 156000 \\
\hline 6 & & Pucung & 13600 & 23 & & Kenteng & 7500 & 44 & & Nglora & 65000 \\
\hline 7 & & Songbanyu & 0 & 24 & & Ponjong & 0 & 45 & & Planjan & 2600000 \\
\hline 8 & & Tileng & 0 & 25 & & Sumber Giri & 18750 & 46 & \multirow{3}{*}{ Semanu } & Candirejo & 39430 \\
\hline 9 & \multirow{3}{*}{ Paliyan } & Giring & 190000 & 26 & \multirow{5}{*}{ Purwosari } & Giriasih & 3950 & 47 & & Dadapayu & 8710.5 \\
\hline 10 & & Karang Asem & 374180 & 27 & & Giricahyo & 810 & 48 & & Ngeposari & 13125 \\
\hline 11 & & Karang Duwet & 0 & 28 & & Girijati & 0 & 49 & \multirow{5}{*}{ Tanjungsari } & Banjarejo & 1375 \\
\hline 12 & \multirow{6}{*}{ Panggang } & Giriharjo & 4200 & 29 & & Giripurwo & 8520 & 50 & & Hargosari & 6440 \\
\hline 13 & & Girikarto & 0 & 30 & & Giritirto & 7200 & 51 & & Kemadang & 15000 \\
\hline 14 & & Girimulyo & 2051.2 & 31 & \multirow{8}{*}{ Rongkop } & Bohol & 1500 & 52 & & Kemiri & 6607.5 \\
\hline 15 & & Girisekar & 2350 & 32 & & Botodayakan & 0 & 53 & & Ngestiharjo & 16760 \\
\hline 16 & & Girisuko & 2100 & 33 & & Karangwuni & 13750 & 54 & \multirow{5}{*}{ Tepus } & Giripanggung & 4500 \\
\hline 17 & & Giriwungu & 1280 & 34 & & Melikan & 15000 & 55 & & Purwodadi & 0 \\
\hline & & & & 35 & & Petir & 3600 & 56 & & Sidoharjo & 1320 \\
\hline & & & & 36 & & Pringombo & 4500 & 57 & & sumber Wungu & 3270 \\
\hline & & & & 37 & & Pucanganom & 5690 & 58 & & Tepus & 0 \\
\hline & & & & 38 & & Semugih & 21500 & 59 & & Wunung & 0 \\
\hline
\end{tabular}

\section{TOTAL POTENSI AIR}

TELAGA DOLIN

$5.319 .168,2 \mathrm{~m}^{3} /$ th 


\section{Siklus air di karst yang 'memakan' karbon di karst Gunungsewu}

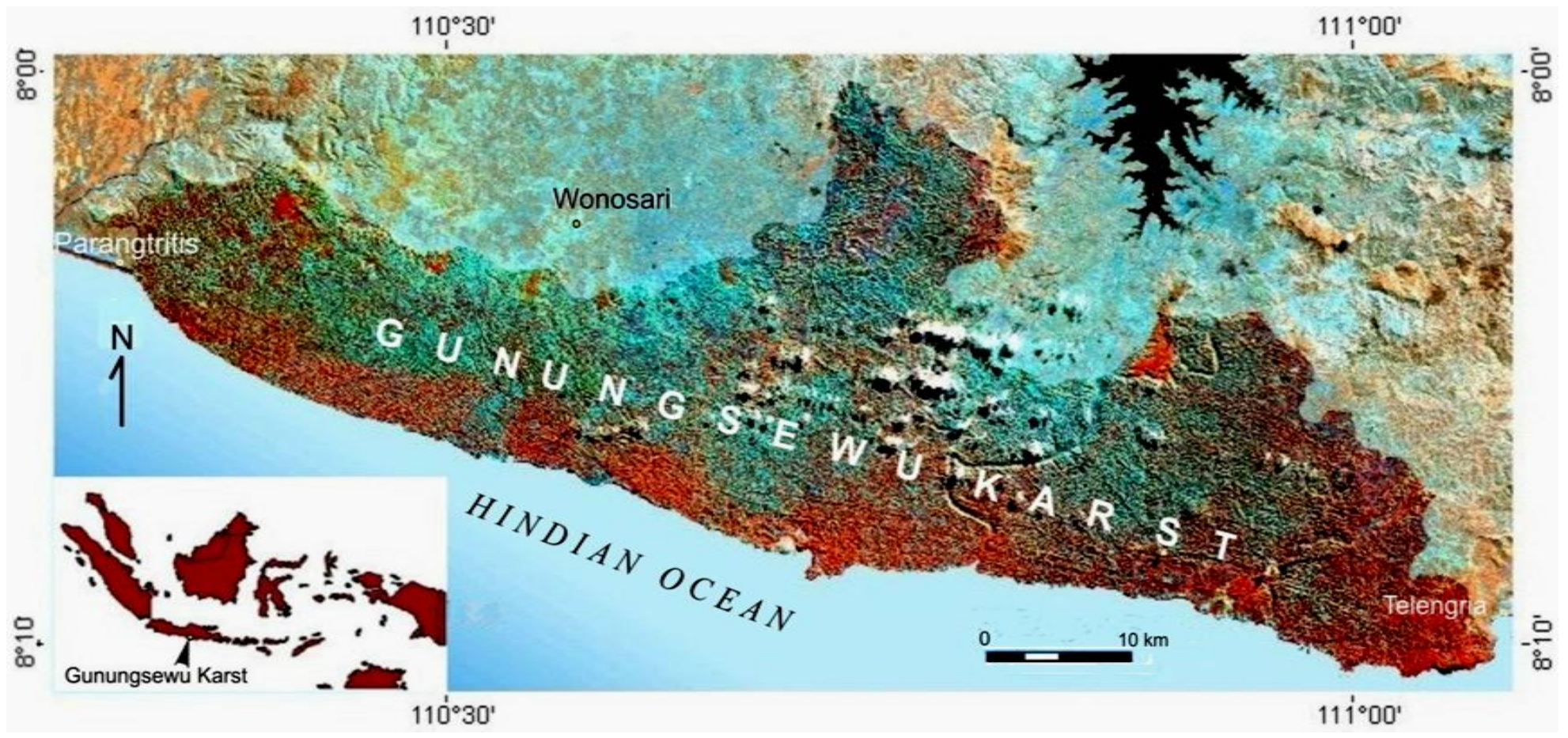

- Area : $1300 \mathrm{~km}^{2}$

- Rocks : Limestone (Wonosari-Punung F.)

- Rainfall : 1500 - 2986 mm/year

- Landuse: Dry field agriculture 


\section{Gunungsewu karst landscape - underground}
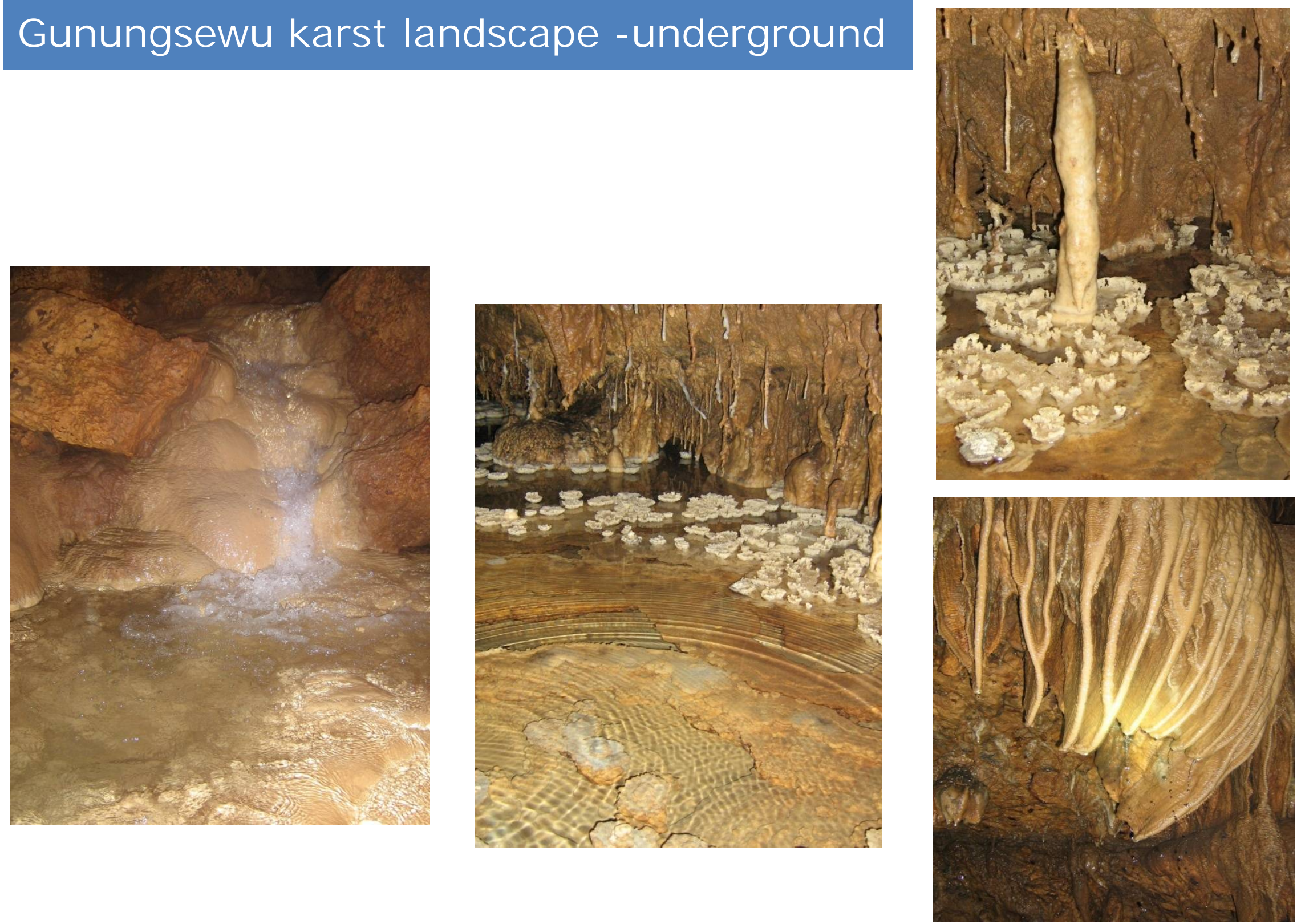

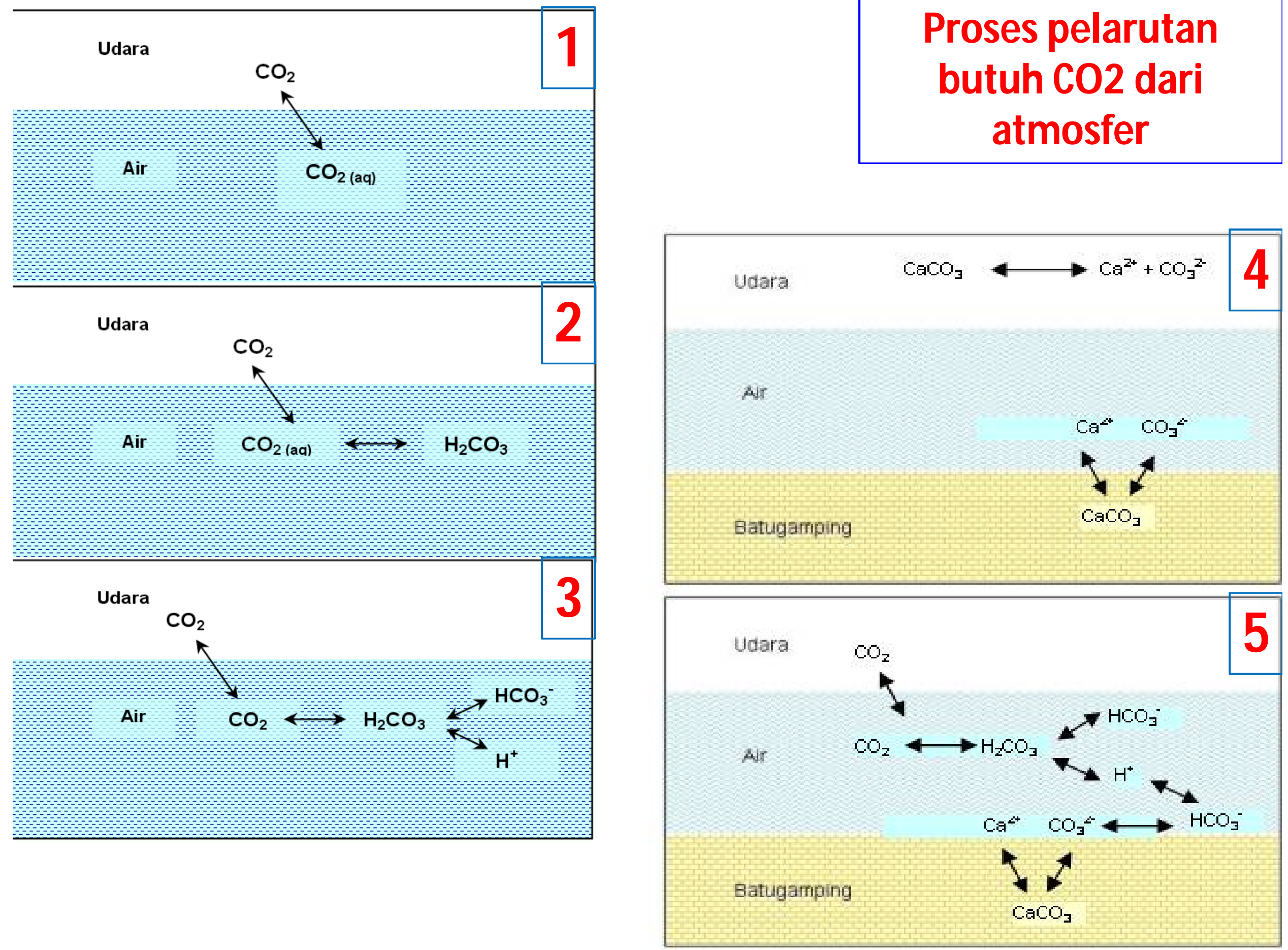


\section{Dissolution Process}

\section{$\mathrm{H}_{2} \mathrm{O}+\mathrm{CO}_{2}+\mathrm{CaCO}_{3} \rightarrow \mathrm{Ca}^{2+}+\mathrm{HCO}_{3}^{-}$}

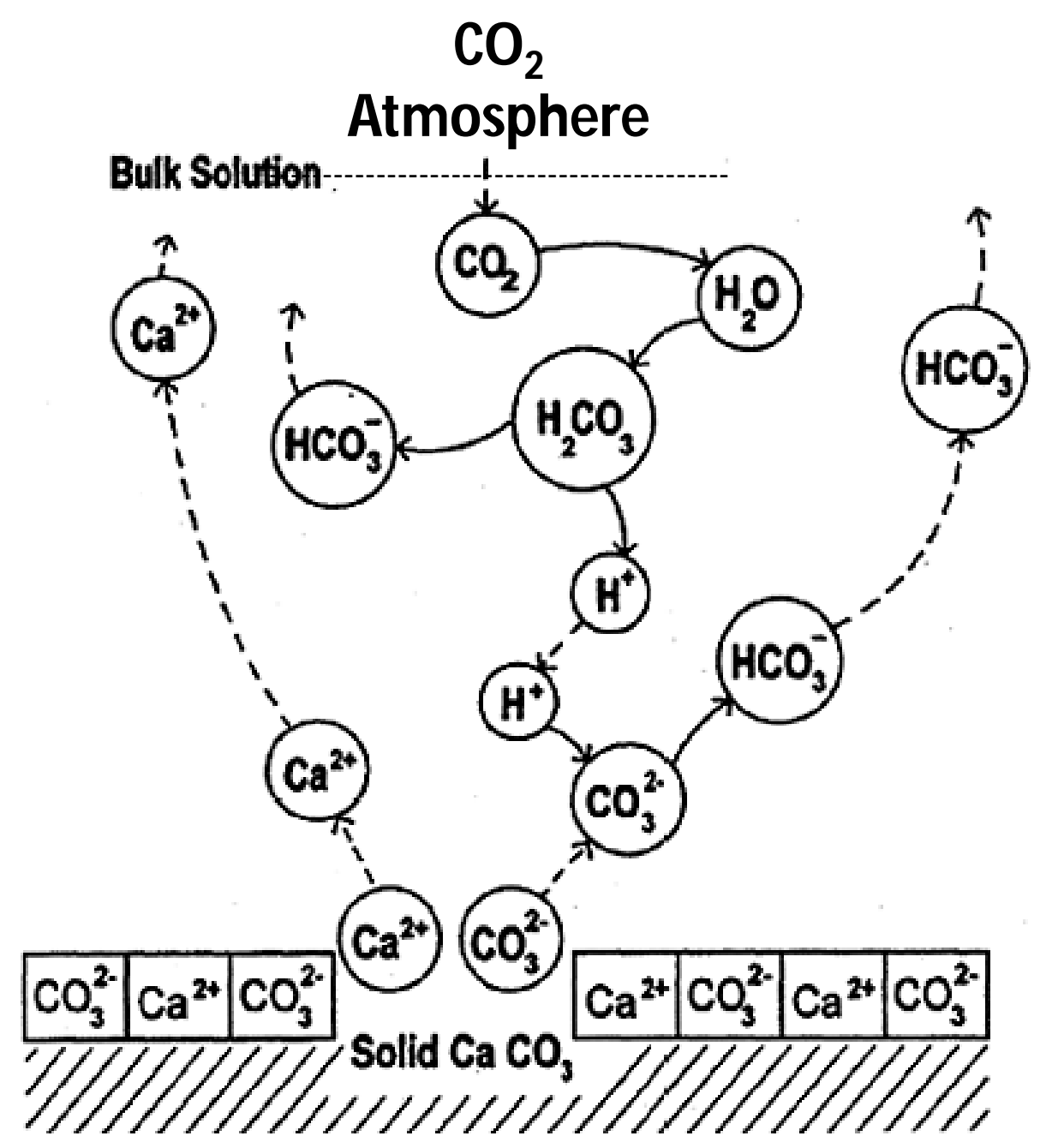

$120 \mathrm{~kg}$ carbon is up-takes from atmosphere during the removal of $1000 \mathrm{~kg}$ (to dissolve limestone)

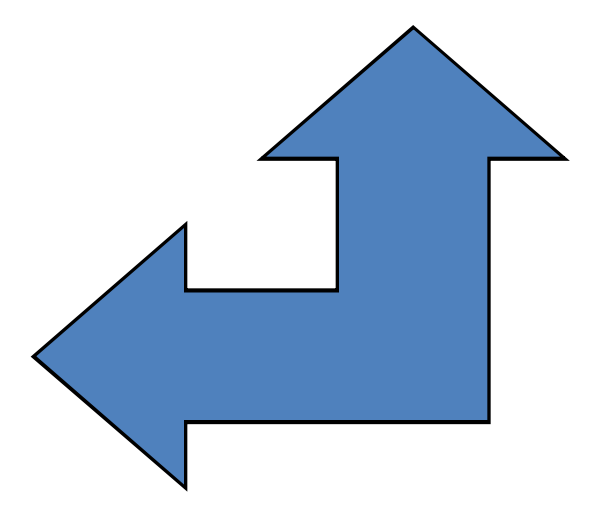




\section{Karst Denudation}

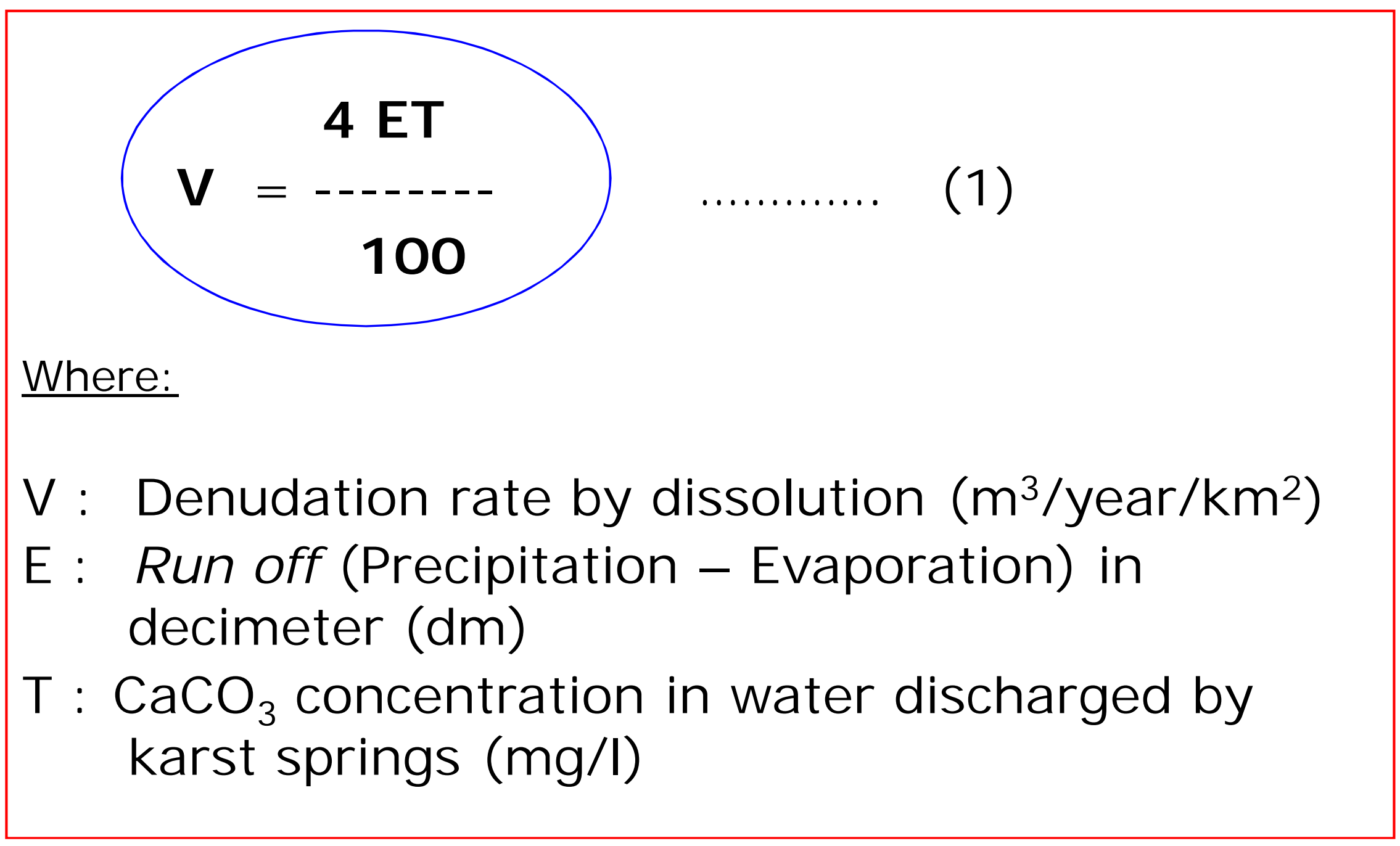


- Average precipitation in Gunung Sewu Karst is $2,051 \mathrm{~mm} /$ year

- Annual potential evapotranspiration (PET) of Gunung Sewu Karst is $\mathbf{1 , 3 6 2 . 9 1 ~ m m}$

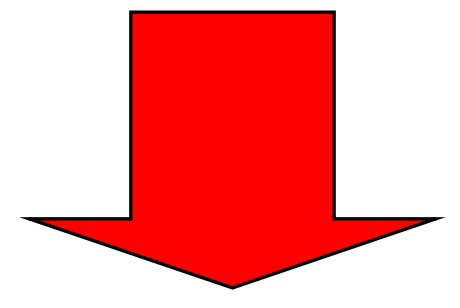

- Annual runoff discharging from Gunung Sewu Karst is $\mathbf{6 8 8} \mathbf{~ m m}$ 
- Average $\mathrm{CaCO}_{3}$ removed from Gunung Sewu Karst is $\mathbf{1 8 5}$ mg/l

- Denudation rate of Gunung Sewu Karst is estimated to be $\mathbf{5 0 . 9 1} \mathrm{m}^{3} / \mathrm{km}^{2} /$ year

- Equivalent to 165,464 ton $\mathrm{CaCO}_{3} /$ year

- Thus, the estimate annual carbon dioxide sequestration in Gunung Sewu Karst through denudation processes is

72,804.16 ton 


\section{Summary}

\begin{tabular}{|l|c|r|r|r|}
\hline \multicolumn{1}{|c|}{ Potensi } & m3/tahun & harga air/m3 (Rp) & Nilai Ekonomi & \multicolumn{1}{c|}{$\%$} \\
\hline Air hujan & 9501661.3 & 1500 & $14.252 .491 .950,-$ & 1.7 \\
\hline Mataair \& SBT & 521337699.4 & 1500 & $782.006 .549 .100,-$ & 95.5 \\
\hline Telaga Doline & 5319168.2 & 1500 & $7.978 .752 .300,-$ & 1.0 \\
\hline & ton/th & carbon trade/ton (US\$) & & \\
\hline Penyerapan karbon & 72804.2 & 195000 & $14.196 .819 .000,-$ & 1.7 \\
\hline & & TOTAL & $\mathbf{8 1 8 . 4 3 4 . 6 1 2 . 3 5 0 , -}$ & 100.0 \\
\hline
\end{tabular}

\section{Prosentase terbesar tetap pada mataair dan sungai bawah tanah karst (95\%)}

